\title{
The Efficacy of Radiofrequency in Facial Rejuvenation
}

\author{
MAI A.A.R. MOHAMMED, M.Sc.*; GHADA F. REZK, M.D.*; SAMIA OTHMAN NASSAR, M.D.* and \\ DAREEN A. MOHAMMED, M.D.**
}

The Departments of Dermatology \& Venereolog* and Pathology**, Faculty of Medicine, Tanta University

\begin{abstract}
Background: The process of skin aging may be classified into intrinsic and extrinsic aging or photoaging. The first is a natural and gradual process. The second is triggered by environmental factors such as excess sun exposure. There are many therapeutic modalities that can improve skin aging. These modalities may be divided into topical agents and procedural agents. Radiofrequency (RF) is one of good procedural modalities to improve skin aging.

Aim of Study: The aim of this study was to evaluate the efficacy and safety of radiofrequency in facial rejuvenation.

Settings and Design: Prospective study.

Patients and Methods: This study included ten patients presented with facial wrinkles. All patients received four RF sessions with three to four weeks interval and followed-up after three month after end of treatment. Patients were assessed by digital photographing and skin biopsies before and after treatment.

Results: Radiofrequency showed favorable results with $40-50 \%$ improvement. There was a significant difference in degree of improvement according to doctors' opinion ad patients' satisfaction after than before treatment.

Conclusion: RF is a safe, acceptable, effective and noninvasive tool for skin rejuvenation that produces favorable results. RF could act as an alternative but not equivalent to other invasive modalities. These results were confirmed by immunohistochemical expression of Matrix Metalloproteinase 1 (MMP1).
\end{abstract}

Key Words: Skin aging - Rejuvenation - Radiofrequency $M M P 1$

\section{Introduction}

THE process of skin aging may be classified into intrinsic and extrinsic aging or photoaging. Intrinsic aging is a natural and gradual process, while extrinsic is triggered by environmental factors as excess exposure to sunlight. Both cause morphological and biomechanical changes in skin [1]

Correspondence to: Dr. Mai A.A.R. Mohammed, The Department of Dermatology \& Venereolog, Faculty of Medicine, Tanta University
There are many therapeutic modalities that can improve skin aging. These modalities are either topical agents or procedural agents. Procedural agents include microdermabrasion, chemical peeling, lasers, and radiofrequency [2].

Radiofrequency (RF) is an effective tool for skin tightening and laxity reduction $[3,4]$. RF relies on the electric property of the tissue and does not require specific chromophore. Therefore, RF is safe for all skin types [5]. The mechanism of RF is to stimulate neocollagenesis by heat production in deep layers of the skin and subcutaneous tissue [6]

\section{Patients and Methods}

\section{Patients:}

This study included ten patients with facial wrinkles, who didn't receive any previous cosmetic treatment or facial surgery. Patients accepted to be included in this study and signed a written consent. All the patients were selected from Out Patient Clinic of Dermatology and Venereology, Tanta University Hospitals during the period from October 2016 to February 2018.

\section{Methods:}

All patients were subjected to the following:

1- Complete history taking including personal history (age, sex, occupation, marital state and special habits), history of sun exposure, family history, present history for any medical condition, and past history of any treatment of rejuvenation in the last six months.

2- Through general and cutaneous examination.

3- Routine laboratory investigations were done including random blood glucose level, bleeding and coagulation time, the patient with abnormal findings were excluded. 
4- Clinical assessment was performed for each patient:

A- Evaluation of the skin phototypes of the patients according to Fitzpatrick classification.

B- Distribution of facial wrinkles: Forehead lines, frown lines, crow's feet, tear trough, nasolabial folds, and marionette lines.

C- Scoring of the patients before and after treatment was done according to Glougau's classification [7] (Table 1).

Table (1): Glogau's classification of photoaging [7]

\begin{tabular}{|c|c|c|}
\hline Group & Typical age & Skin features \\
\hline I Mild & $\begin{array}{l}\text { The } \\
20 s-30 s\end{array}$ & $\begin{array}{l}\text { Early photoaging } \\
\text { Mild dyschromia } \\
\text { No keratoses } \\
\text { Minimal wrinkling } \\
\text { Minimal, no makeup } \\
\text { Minimal, or no scarring }\end{array}$ \\
\hline II Moderate & $\begin{array}{l}\text { The late } \\
30 \mathrm{~s}-40 \mathrm{~s}\end{array}$ & $\begin{array}{l}\text { Early senile lentigines } \\
\text { Dyschromia } \\
\text { Early actinic keratoses } \\
\text { Parallel smile lines } \\
\text { Early wrinkling } \\
\text { Some foundation wore } \\
\text { Mild acne scarring }\end{array}$ \\
\hline III Advanced & $\begin{array}{l}\text { Usually aged } \\
50-65\end{array}$ & $\begin{array}{l}\text { Dyschromia, telangiectasias } \\
\text { Visible keratoses } \\
\text { Wrinkling at rest } \\
\text { Always wears makeup } \\
\text { Moderate acne scarring }\end{array}$ \\
\hline IV Severe & $\begin{array}{l}\text { Patient age } \\
60-75\end{array}$ & $\begin{array}{l}\text { Actinic keratoses } \\
\text { Prior skin cancers } \\
\text { Wrinkling throughout } \\
\text { Makeup cakes \& cracks } \\
\text { Severe acne scarring }\end{array}$ \\
\hline
\end{tabular}

5- Facial digital photographs: (Frontal, right and left views) were taken for every patient using a digital camera (Canon IXUS 150, 16.2 mega pixels) at baseline, every session and after completing the treatment.

The technique of radiofrequency therapy:

Five treatment areas were identified for each patient:

1- Left and right cheek, nasolabial fold.

2- Left and right lower eyelid.

3- Left and right upper eyelid.

4- Submental area.

5- Forehead.
- The treatment areas were cleaned with alcohol prior to the treatment.

- No anesthesia, including topical anesthesia, was utilized during this study.

- Ultrasound gel was applied to all treatment areas. The handpiece of the device (The Viora REACTION TM-USA) was then gently applied to the treatment area to create constant, uniform coupling Fig. (1).

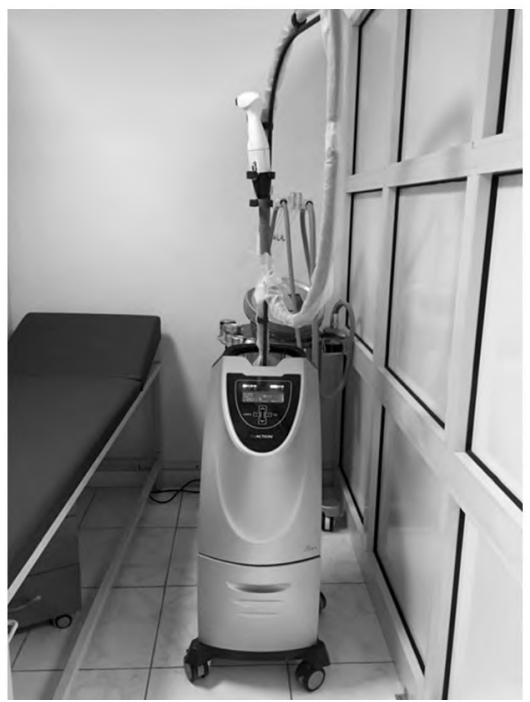

Fig. (1): Viora reactionTM.

- Treatment was applied according to the protocol for the specific treatment area. For lower face and perioral regions, modes I and II ( 0.8 and $1.7 \mathrm{MHz}$, respectively) were used, while forehead and cheekbone areas, superficial frequency was used (mode III, $2.45 \mathrm{MHz}$ ).

- The probe was moved over each treatment area in circular manner to uniformly heat the area.

- Each treatment session duration lasted an average of 25 minutes.

Post-treatment care:

- Patients were instructed to apply anti-inflammatory ointment immediately after session followed by application of a bland moisturizer for few days.

- All the patients were instructed to apply sunscreen with (SPF 30) or more to the entire face before exposure to sun.

- All the patients were advised to avoid the use of other rejuvenation modalities during the study.

- Any possible complications, including edema, erythema, burning sensation, hypopigmentation, hyperpigmentation, infection, and scarring were recorded at each visit. 
Histopathological evaluation of the treatment efficacy:

Punch biopsy:

Punch skin biopsies (two $\mathrm{mm}$ ) were taken from every patient before treatment and the other skin biopsy were taken after the last session.

The pre-treatment skin biopsies were examined by routine hematoxylin and eosin stains ( $\mathrm{H} \& \mathrm{E}$ ) then immunohistochemical examination for both pretreatment and post-treatment skin biopsies using Matrix Metalloproteinase 1 (MMP 1) to detect its expression in the studied cases and to evaluate treatment-induced changes.

\section{Immunohistochemical staining [8] :}

A- The antibody used: Matrix Metalloproteinase 1 mouse monoclonal antibody (MMP-1 Antibody (6A5)).

\section{B- Immunohistochemical staining procedure:}

- The paraffin sections were deparaffinized, hydrated, and placed in $10 \%{ }_{\mathrm{H} 2 \mathrm{O} 2}$ to block endogenous peroxidase activity.

- Unmasking of antigenic sites was carried out by transmitting sections into a jar containing 0.001 mol/1 citrate buffer ( $\mathrm{pH} 6)$.

- This was followed by boiling in a microwave for four min at temperature grade VIII followed by two min at grade II. Blocking with serum blocking solution for ten min was performed.

- Slides were incubated with the primary antibody (MMP-1 proteins) at room temperature for two hr.

- After washing they were incubated with biotinylated secondary antibodies (ABC Kit, 1:200). Freshly prepared.

- Diaminobenzidine was used as a chromogen.

- Sections were incubated with diaminobenzidine for ten min and then washed with tap water, counterstained with hematoxylin, dehydrated, and mounted.

\section{C- Interpretation of immunohistochemical staining} [9]: Immunoreactivities were semiquantitatively evaluated as *"negative" (-) when no positive cells were found.

*"Mild" $(+)$ when positive cells accounted for $<25 \%$ of the total number.

* "Moderate" $(++)$ when $21 \%$ to $50 \%$ of cells were positive.

*“Diffuse" $(+++)$ when $<50 \%$ of cells were positive.

\section{Statistical analysis of the data [10]:}

Data were fed to the computer and analyzed using IBM SPSS software package Version 20.0. (Armonk, NY: IBM Corp) [11] . Qualitative data were described using number and percent. The Kolmogorov-Smirnov test was used to verify the normality of distribution quantitative data were described using range (minimum and maximum), mean, standard deviation and median. Significance of the obtained results was judged at the $5 \%$ level.

\section{Results}

This study included ten females. Their ages ranged from 25-50 years with a mean \pm SD 36.10 \pm 6.92 and median 38. Skin phototyping for patients according to Fitzpatrick classification, three patients $(30 \%)$ were phototype II, six patients $(60 \%)$ were phototype III and one patient (10\%) was phototype IV.

Evaluation of efficacy of therapeutic procedures:

According to Glauge's score, two patients (20\%) were grade II and eight patients $(80 \%)$ were grade III and after RF treatment two patients $(20 \%)$ became grade I and eight patients $(80 \%)$ became grade II (Table 2).

Table (2): Difference in Glauge's before and after RF treatment.

\begin{tabular}{|c|c|c|c|c|c|}
\hline & \multirow{2}{*}{$\begin{array}{l}\text { Glauge's } \\
\text { score }\end{array}$} & \multicolumn{2}{|c|}{$\mathrm{RF}(\mathrm{n}=10)$} & \multirow{2}{*}{$x^{2}$} & \multirow{2}{*}{$\mathrm{MC}_{p}$} \\
\hline & & No. & $\%$ & & \\
\hline \multicolumn{6}{|c|}{ Before: } \\
\hline & $\mathrm{I}$ & 0 & 0.0 & 4.946 & 0.099 \\
\hline & II & 2 & 20.0 & & \\
\hline & II & 8 & 80.0 & & \\
\hline \multicolumn{6}{|c|}{ After: } \\
\hline & I & 2 & 20.0 & 4.942 & 0.101 \\
\hline & II & 8 & 80.0 & & \\
\hline & II & 0 & 0.0 & & \\
\hline & $p_{1}$ & \multicolumn{2}{|c|}{$0.002 *$} & & \\
\hline \multicolumn{6}{|c|}{$\begin{aligned} \mathrm{xC}^{2} & : \text { Chi square test for comparing between the three groups. } \\
& : p \text {-value for Monte Carlo for Chi square test for comparing } \\
& \text { between the three groups. }\end{aligned}$} \\
\hline $\begin{array}{l}p_{1} \\
*\end{array}$ & $\begin{array}{l}p \text {-value for } \mathrm{M} \\
\text { before and af } \\
\text { Statistically }\end{array}$ & $\begin{array}{l}\text { ginal } \mathrm{H} \\
\text { in ea } \\
\text { nifica }\end{array}$ & $\begin{array}{l}\text { nogenei } \\
\text { group. } \\
\text { at } p \leq 0 \text {.C }\end{array}$ & Test for & mparing between \\
\hline
\end{tabular}

Regarding patient satisfaction after treatment, the mean was \pm SD $45 \pm 7.07$ and median 50 .

The degree of improvement according to doctors' opinion ranged from $40-50 \%$ with a mean \pm SD $44 \pm 15.16$ and median 40 (Table 3 ).

There was significant difference in improvement in Glauge's score, patients' satisfaction and doctors' opinion after than before treatment. 
Table (3): Patients' satisfaction and doctors' opinion after RF treatment.

\begin{tabular}{lllc}
\hline & $\mathrm{RF}(\mathrm{n}=10)$ & $\mathrm{F}$ & $p$ \\
\hline Patient satisfaction: & & & \\
Min.-max. & $30.0-50.0$ & $28.533^{*}$ & $<0.001 *$ \\
Mean \pm SD. & $45.0 \pm 7.07$ & & \\
Median & 50.0 & & \\
Doctor opinion: & & & \\
Min.-max. & $40.0-50.0$ & $7.163^{*}$ & $0.003^{*}$ \\
Mean \pm SD. & $44.0 \pm 5.16$ & & \\
Median & 40.0 & & \\
\hline
\end{tabular}

$\mathrm{F}, p: \mathrm{F}$ and $p$-values for ANOVA test. Statistically significant at $p \leq 0.05$.
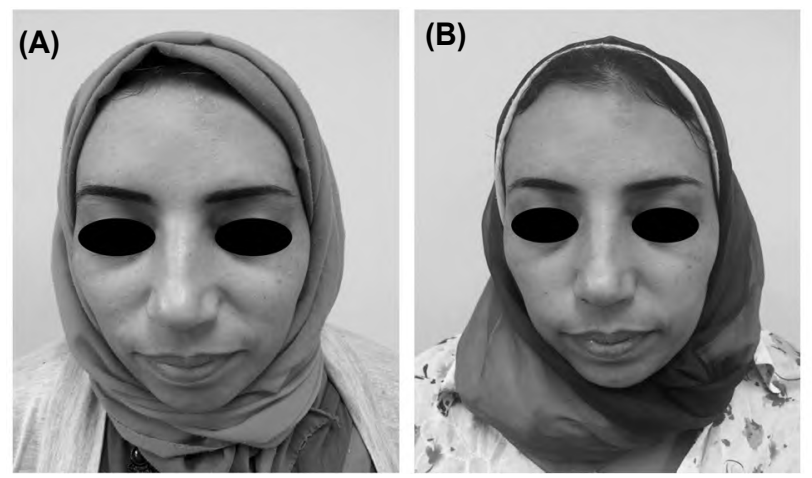

Photo (2): Female patient 36 year old. (A) Before treatment, (B) After treatment (4 RF sessions) showing mild improvement.
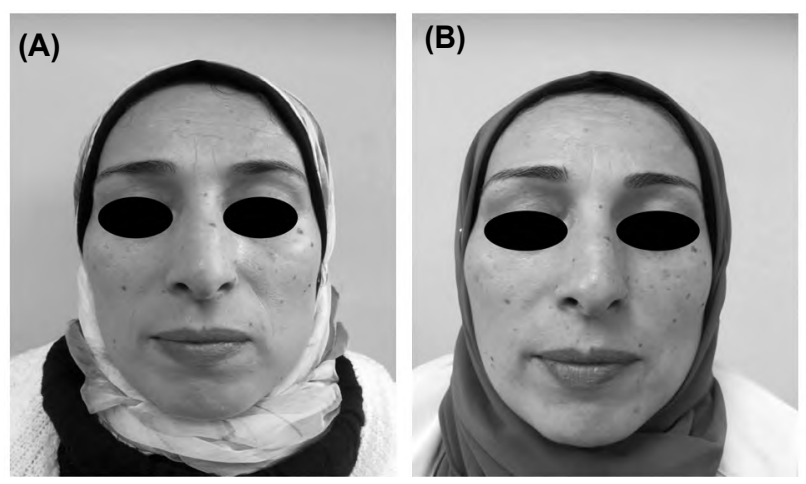

Photo (1): Female patient 30 year old. (A) Before treatment, (B) After treatment (4 RF sessions) showing moderate improvement.
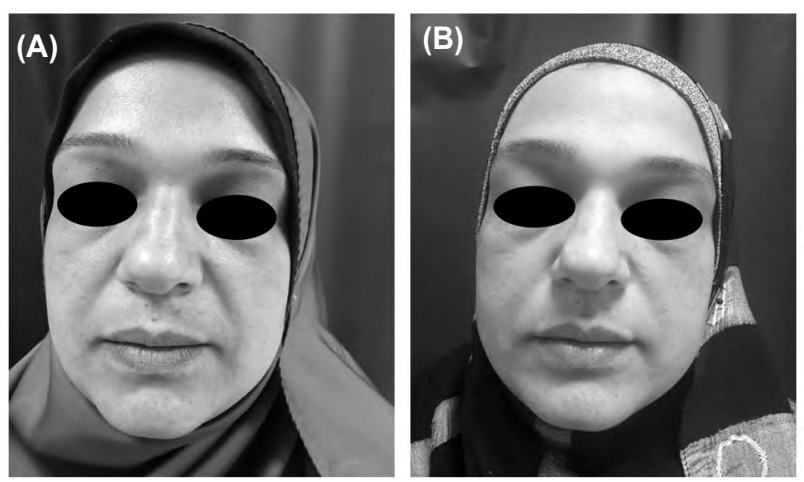

Photo (3): Female patient 40 year old. (A) Before treatment, (B) After treatment (4 RF sessions) showing mild improvement.
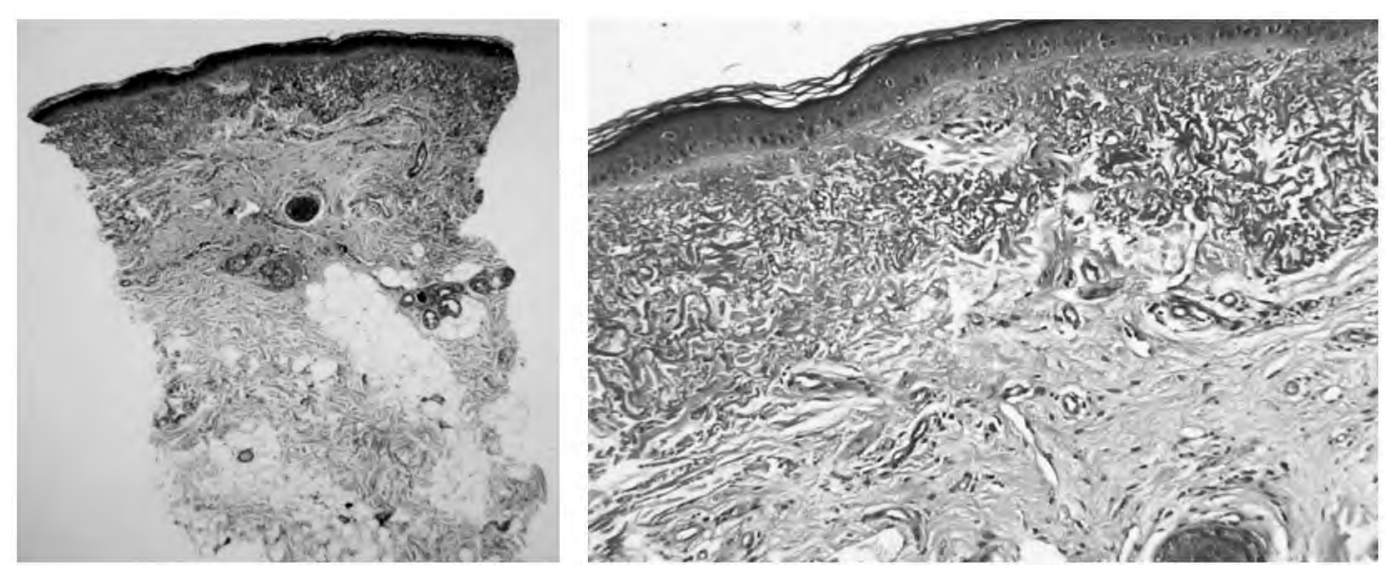

Photo (4): Pre-treatment H \& E sections showed epidermal atrophy, thin dermoepidermal junction and decreased amount of dermal collagen (H \& E: A X100, B X200).

Regarding side effects, five patients (50\%) experienced pain sensation and two patients $(20 \%)$ had transient erythema.

\section{Histopathological results:}

Haematoxyline and eosin:

Pretreatment H \& E sections showed epidermal atrophy, thin dermoepidermal junction and decreased amount of dermal collagen.
After RF, sections showed mild increase in dermal density and number of collagen fibers, mild increase in thickness of dermoepidermal junction and dermal thickness.

\section{Matrix metalloproteinase 1 (MMP1) expression:}

Pre-treatment sections showed focal (+) expression of MMP1 in all groups. After treatment, focal $(+)$ expression in eight patients $(80 \%)$ and moderate 
$(++)$ expression in two patients $(20 \%)$ showing no statistically significant difference.

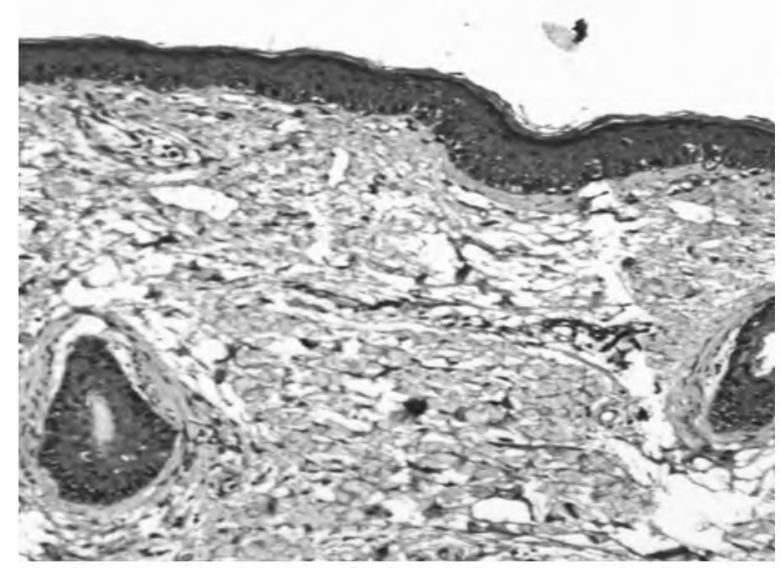

Photo (5): Representative example for pre-treatment expression of MMP1: Focal expression (MMP1 X200).
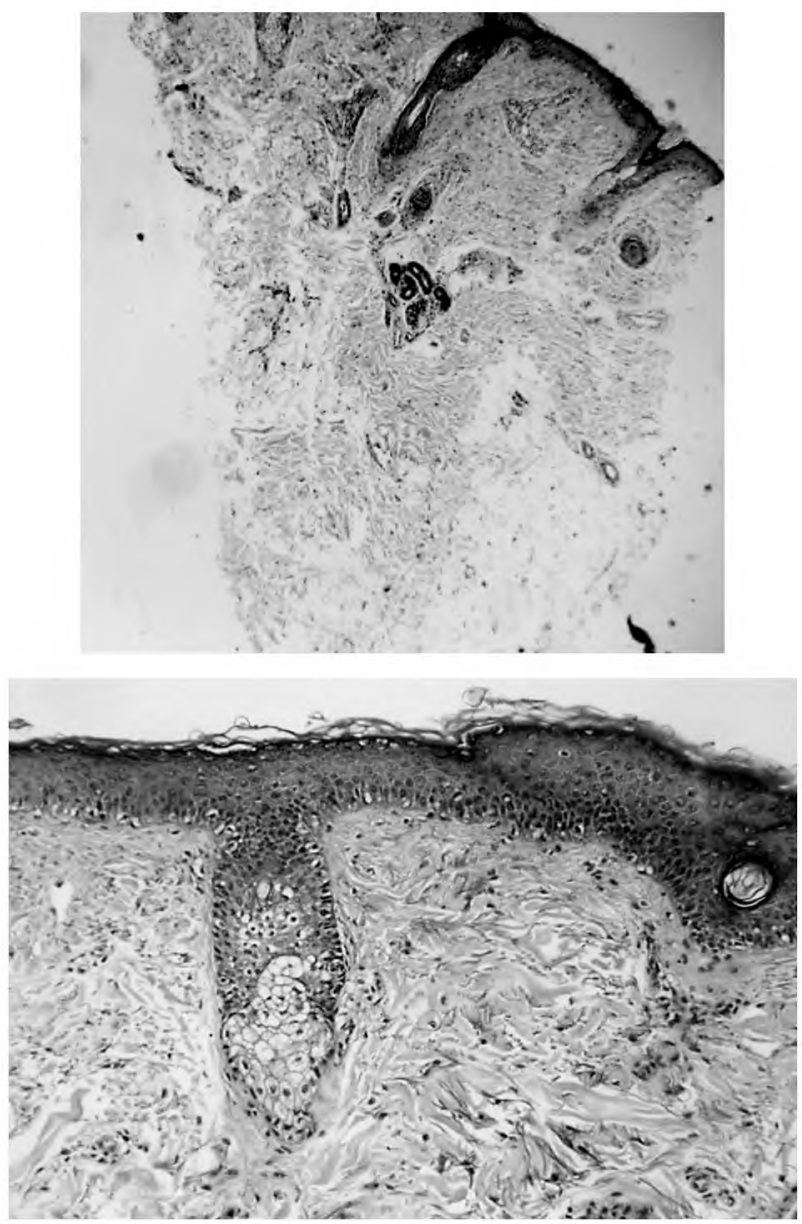

Photo (6): Post RF: H \& E sections showed mild increase in dermal density and number of collagen fibers, mild increase in thickness of dermoepidermal junction and dermal thickness. (H \& E A X100, B X200).

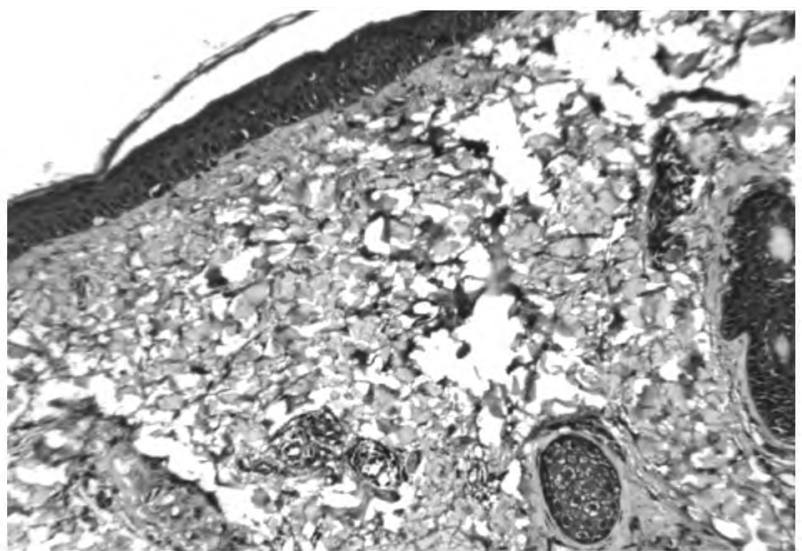

Photo (7): Post RF: MMP1 focal expression (MMP1 X200).

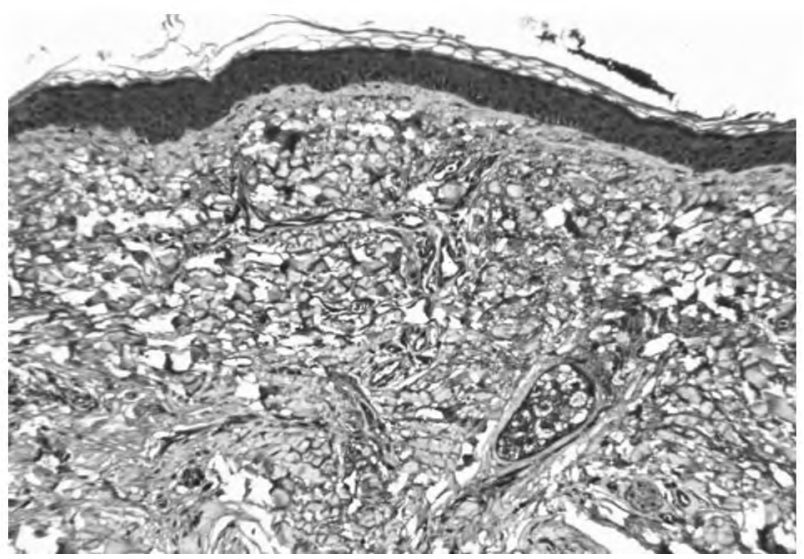

Photo (8): Post RF MMP1 moderate expression (MMP1 X200).

\section{Discussion}

There are two main types of skin aging: Intrinsic and extrinsic (photoaging). Extrinsic aging is exacerbated by environmental factors such as sun exposure and smoking. Intrinsic aging represent the genetic background and increased by time [12]

Many anti-aging agents and interventions have been introduced for improvement of aged skin, including topical agents, chemical peeling, dermabrasion laser and light therapy and radiofrequency devices [13]

Radiofrequency devices represent a valuable and non-invasive technology in treatment of skin aging, as it is a safe and effective treatment for a wide range of skin problems such as wrinkle reduction, cellulite improvement, laxity, body and skin contouring improvement [14]. Radiofrequency thermal energy seems to have various biological effects including immediate effects on collagen structure and fibroblast stimulation leading to synthesis of new collagen and elastic fibers [15]. 
The aim of this work was to evaluate the efficacy and safety of RF in facial rejuvenation.

In this study the percentage of patients' satisfaction was $30-50 \%$ with the mean \pm SD $45 \pm 7.07$ and median 50. The degree of improvement according to doctors' opinion, ranged from 40-50\% with a mean \pm SD $44 \pm 15.16$ and median 40 . According to Glogau's score, two patients (20\%) were grade II and eight patients (80\%) were grade III and after RF treatment, two patients (20\%) became grade I and eight patients (80\%) became grade II.

Fritz et al., (2004) report a study comparing multiple RF treatments to a single RF treatment, for mild to moderate laxity of face. They assumed that two RF treatments produced significantly better results than a single treatment, with overall improvements were modest in the two groups [16] Another study contained 16 females reported the following results, in treatment of the jowls, a moderate improvement $(51-75 \%)$ was recorded in two of the patients and a significant improvement $(>75 \%)$ in one patient. In treatment of the cheeks, a moderate improvement $(51-75 \%)$ was recorded in three of the patients and a significant improvement (>75\%) in two [17] . Friedman and Gilead, (2007) used the combination of a unipolar handpiece and a bipolar handpiece for facial rejuvenation with moderate to significant improvement in 69\% of the patients [18]. Yin et al., (2015) mentioned that the explanation of decreased response and satisfaction of participants in follow-up visits with $\mathrm{RF}$ treatment is due to delayed neocollagenesis and long-term wound-healing process, with slowly progressive changes [19].

Regarding MMP1 expression for this group, after treatment, focal $(+)$ expression in eight patients $(80 \%)$ and moderate $(++)$ expression in two patients $(20 \%)$. There was no statistical significance in MMP 1 expression after than before RF treatment.

El-Domyati (2011), showed a modest increase in epidermal thickness at the end of treatment and after 3 months from last session, especially in the granular cell layer with a significant increase in both type I and III collagens [2]

Regarding side effects, immediately after session, the treated skin of all cases showed mild erythema, which was temporary. No burns or post inflammatory hyperpigmentations were detected. No additional adverse events were noted [20]. In our study, patients experienced mild pain and transient erythema.

\section{Conclusion:}

In conclusion, RF is an effective and tolerable procedure that can be used to tighten skin, and reduce facial skin laxity and fine wrinkles. This tool stimulates collagen formation and improve the clinical, and histopathological signs of aging, with the advantage that it's non-invasive procedure and with little downtime.

\section{Recommendations:}

1- Other studies are recommended to be done with larger number of patients and more number of sessions.

2- Well-designed controlled studies are required to determine the long term effectiveness of these procedures and to compare other procedures that also promote facial rejuvenation.

3- Standardization of a regimen for managing skin aging on both prophylactic and therapeutic levels.

\section{References}

1- ARAÚJO A.R., SOARES V.P., SILVA F.S. and MOREIRA T.S.: Radiofrequency for the treatment of skin laxity: Mith or truth. An Bras. Dermatol., 90 (5): 707-21, 2015.

2- EL-DOMYATI M., EL-AMMAWI T.S., MEDHAT W., MOAWAD O., BRENNAN D., MAHONEY M.G., et al.: Radiofrequency facial rejuvenation: Evidence-based effect. J. Am. Acad. Dermatol., 64 (3): 524-35, 2011.

3- KUSHIKATA N., NEGISHI K., TEZUKA Y., TAKEUCHI K. and WAKAMATSU S.: Non-Ablative Skin Tightening With Radiofrequency in Asian Skin. Lasers Surg. Med., 36 (2): 92-7, 2005.

4- WAKADE D.V., NAYAK C.S. and BHATT K.D.: A Study Comparing the Efficacy of Monopolar Radiofrequency and Glycolic Acid Peels in Facial Rejuvenation of Aging Skin Using Histopathology and Ultrabiomicroscopic Sonography (UBM)-An Evidence Based Study Acta Medica, 59 (1): 14-7, 2016.

5- BRIGHTMAN L., GOLDMAN M.P. and TAUB A.F. Sublative Rejuvenation: Experience with a New Fractional Radiofrequency System for Skin Rejuvenation and Repair. J. Drugs Dermatol., 8 (11): 9-13, 2009.

6- ANOLIK R., CHAPAS A.M., BRIGHTMAN L.A. and GERONEMUS R.G.: Radiofrequency Devices for Body Shaping: A Review and Study of 12 Patients. Semin. Cutan. Med. Surg., 28 (4): 236-43, 2009.

7- GLOGAU R.G.: Chemical peeling and aging skin. J. Geriatric. Dermatol., 62 (5): 30-50, 1994.

8- DEIF E., EL-SHIEMY H., LOTFI R. and MOHAMMED G.: Immuno-histochemical and light and electron microscopic study of the basement membrane in photoaged skin. Egypt J. Histology, 473-9, 2014.

9- MASSI D., FRANCHI A., KETABCHI S., PAGLIERANI M., PIMPINELLI N. and SANTUCCI M.: Expression 
and prognostic significance of matrix metalloproteinases and their tissue inhibitors in primary neuroendocrine carcinoma of the skin. Hum. Pathol., 34 (1): 80-8, 2003.

10- KOTZ S., BALAKRISHNAN N., READ C.B. and VIDAKOVIC B.: Encyclopedia of statistical sciences. 2 nd ed. Hoboken, N.J.: Wiley-Interscience, 2006.

11-KIRKPATRICK L.A. and FEENEY B.C.: A simple guide to IBM SPSS statistics for Version 20.0. Student ed. Belmont, Calif.: Wadsworth, Cengage Learning, 2013.

12- KRUTMANN J., BOULOC A., SORE G., BERNARD B.A. and PASSERON T.: The skin aging exposome. J. Dermatol. Sci., 85 (3): 152-61, 2017.

13-LIPOZENCIC J. and BUKVIC MOKOS Z.: Dermatologic lasers in the treatment of aging skin. Acta Dermatovenerol. Croat., 18 (3): 176-80, 2010.

14- SADICK N.S., NASSAR A.H., DORIZAS A.S. and ALEXIADES-ARMENAKAS M.: Bipolar and multipolar radiofrequency. Dermatol. Surg., 4 (12): S174-S179, 2014.

15- GOLD M.H.: Noninvasive skin tightening treatment. The
Journal of Clinical and Aesthetic Dermatology, 8 (6): 14$8,2015$.

16- FRITZ M., COUNTERS J.T. and ZELICKSON B.D. Radiofrequency treatment for middle and lower face laxity. Arch. Facial Plast. Surg., 6 (6): 370-3, 2004.

17-BELENKY I., MARGULIS A., ELMAN M., BAR-YOSEF U. and PAUN S.D.: Exploring channeling optimized radiofrequency energy: A review of radiofrequency history and applications in esthetic fields. Adv. Ther., 29 (3): 249-66, 2012.

18- FRIEDMAN D.J. and GILEAD L.T.: The use of hybrid radiofrequency device for the treatment of rhytides and lax skin. Dermatol. Surg., 33: 543-51, 2007.

19- YIN R., CHENG Q. and HAMBLIN M.R.: Radiofrequency technology. In: Yin R, Cheng Q, Hamblin MR. Skin photoaging. Morgan \& Claypool Publishers, 1-4, 2015.

20- YOKOYAMA Y., AKITA H., HASEGAWA S., NEGISHI K., AKAMATSU H. and MATSUNAGA K.: Histologic study of collagen and stem cells after radiofrequency treatment for aging skin. Dermatol. Surg., 40 (4): 390-7, 2014. 


\section{فاعلية التردد الحرارى فى إستعادة نضاره الوجه}

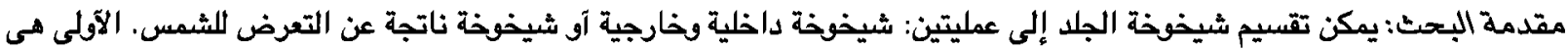

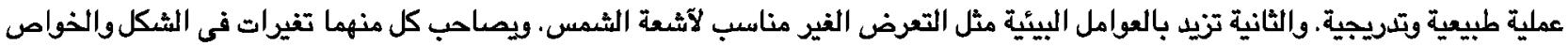
الميكانيكية الحيوية البشرة.

هناك العديد من الطرق العلاجية التى يمكن آن تحسن شيخوخة الجلد . ويمكن تقسيم هذه الطرق إلى طرق موضعية وطرق إجرائية. تثمل الطرق الإجرائية التقشير الكيميائي، السنفرة، وآشعة الليزر، والترنية التردد الحرارى.

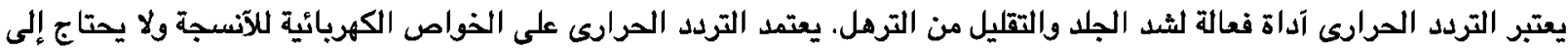

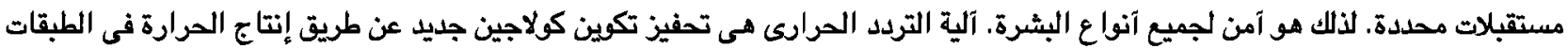

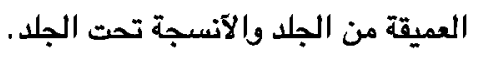
الهدف من الدراسة: الهدف من هذا البحث هو تقييم فاعلية وآمان التردد الحرارى ون فى إستعادة نضارة الوجه..

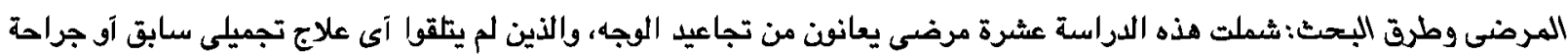

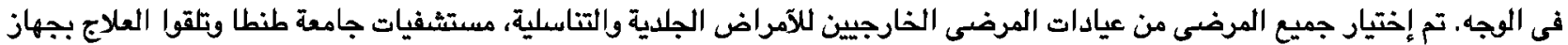

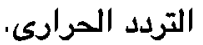

الآشتخاص المدروسون خضعوال : آخذ التاريخ المرضى، فحص إكلينيكى عام وموضعى اللجلد والفحوص المعملية الروتينية. تم الحصل على عينة جلد صغيرة الحجم (rمم) قبل بدء العلاج ويعد ع جلسعات من العلاج وآعدت العينة من آجل: • • صبغة الهيماتوكسيلين والآيوسين الرتينية. • • صبغة إم إم بى المبغ المناعية.

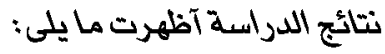
• كان هنال تحسن ملحوظ فى درجة مقياس جلوجو ورضى المرضى وحسب رآى الآطباء بعد عن قبل العلاج. • كانت هناك زيادة فى التعبير المناعى للإم إم بى ا ولكن زيادة ليست ذات دلالة إحصائية.

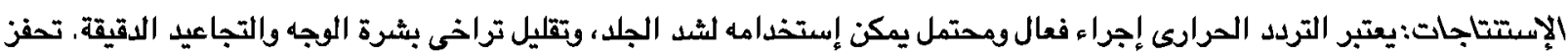

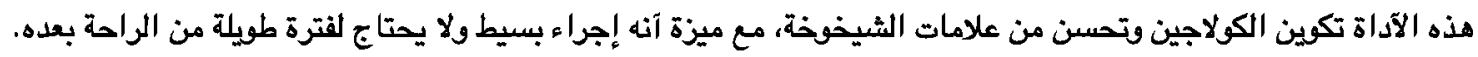
التوصيات: ا - يوصى بإجراء دراسات آخرى مع عدد آكبر من المرضى وعدد آكبر من الجلسات. Y- مطلوب دراسات مصممة بشكل جيد لتعديد فعالية هذه الإجراءات على المدى الطويل ومقارنتها بالإجراءات الآخرى لإستعادة نضارة بشرة

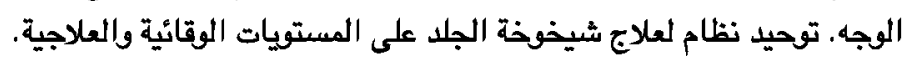

